\title{
Characterization of Finfish Hatchery Waste for Value Added Product
}

\author{
Sujjat Al Azad*, Mohammad Tamrin Bin Mohamad Lal, Al-Najib Bin Benjamin \\ Borneo Marine Research Institute, University Malaysia Sabah, Kota Kinabalu, Sabah, Malaysia \\ Email: *sujjat@ums.edu.my
}

How to cite this paper: $\mathrm{Al}$ Azad, S., Lal, M.T.B.M. and Benjamin, A.-N.B. (2020) Characterization of Finfish Hatchery Waste for Value Added Product. Advances in Bioscience and Biotechnology, 11, 73-79. https://doi.org/10.4236/abb.2020.113006

Received: February 5, 2020

Accepted: March 10, 2020

Published: March 13, 2020

Copyright $\odot 2020$ by author(s) and Scientific Research Publishing Inc. This work is licensed under the Creative Commons Attribution International License (CC BY 4.0).

http://creativecommons.org/licenses/by/4.0/

(c) (i) Open Access

\begin{abstract}
Commercial fish hatchery generates waste both organic and inorganic; the sources are primarily from uneaten food and fish feces. Conventional methods of treating hatchery wastes will increase the operating cost and become extra burden in production. It is necessary to develop a new research application of this nonconventional resource and reduce the negative impacts of hatchery waste on the environment. The whole project is to utilize hatchery waste through bioprocess for probiotic fortified live feed production. In this study, the chemical composition of hatchery waste was determined to understand the suitability waste to get value-added derived products through bioprocess. Composite samples were collected everyday and dried in an oven at a temperature of $65^{\circ} \mathrm{C}$ until complete dryness. Dried samples were mixed well and grinded into fine powder. The analytical parameters like total solids, ammonium nitrogen, nitrite, nitrate and phosphate were determined from the freshly collected samples. Total nitrogen, total phosphorus and total potassium were determined from the dry samples. Total solids, ammonium nitrogen, nitrite, nitrate and phosphate-phosphorus were observed in the ranged from $75-82 \mathrm{mg} / \mathrm{L}, 0.25-8.5 \mathrm{mg} / \mathrm{L}, 0.05-1.9 \mathrm{mg} / \mathrm{L}, 0.04-6.7 \mathrm{mg} / \mathrm{L}$ and $4.1-16.7 \mathrm{mg} / \mathrm{L}$ respectively. On the other hand, the mean content of $3.75 \%$ total nitrogen, $1.80 \%$ total phosphorus and $0.15 \%$ potassium were determined in dry hatchery wastes. The analytical parameters are useful and demonstrate that the nutrients in both fresh and dry waste will be supportive for the growth of microbes in the bioprocess system.
\end{abstract}

\section{Keywords}

Hatchery Waste, Nutrients, Bioprocess, Microbe and Value Added Product

\section{Introduction}

The organic loading in wastewater generated from fin fish hatchery is compara- 
tively less than the loading in waste generated from the grow-out aquaculture farming system. In terms of quality and quantity waste water they are different [1]. Fish hatchery waste can be classified into two categories, soluble and solid waste and they are both organic and inorganic. The sources of wastewater are primarily from uneaten food and fish feces, which is 30 percent unconsumed dry feed and 30 percent consumed food egested as fecal materials [2]. Nutrients like nitrogen and phosphorus are considered as major waste components of fish hatchery, if discharged causes eutrophication problem and encourage harmful algal bloom. Conventional methods of treating hatchery wastes will increase the operating cost and become extra burden in production. These nutrients rich wastewater can be utilized as substrate for value added product. It is necessary to develop a new research application of this nonconventional resource and reduce the negative impacts of hatchery waste on the environment. These wastes commonly contained $7 \%-32 \%$ of the total nitrogen (TN) and $30 \%-84 \%$ of the total phosphorus (TP). All fish hatchery designed with the conventional method for the treatment of wastewater which includes solids removal, ammonia oxidation, aeration and disinfection [2]. These conventional methods of treating hatchery wastes increase production cost several times. This nutrient rich non-conventional resource can properly be utilized into value added substances. It is therefore necessary to develop new research application of converting this waste into a value added product rather than to use uneconomic conventional method.

In addition decomposition of waste has been proven to be effective in the increase of nutrients in culture media. No information is available in the use probiotic bacteria of purple non-sulfur bacteria to utilize fish hatchery waste in the decomposition process to improve the nutritional values of media. Purple non-sulfur bacteria (PNSB) Rhodopseudomonas palustris and Rhodovulum sulfidophilum are potential species in the utilization of food waste, effectively in the utilization of organic matter [3] [4]. Growth characteristic of PNSB, Afifella marina strain ME (KC205142), as well as production of exo-polymeric substances like enzymes and nucleic acid has been documented [5]. The exo-polymeric substances like amylase, protease and cellulose are produced by these bacteria [5] capable of bio-conversion of fish hatchery waste material into value added product. Using viable purple non sulfur bacterium in the decomposition of fish hatchery waste is another alternative way to prepare single cell detritus particles or other live feed such as aquatic worm can easily utilize for their growth to produce better biomass in term of yield and proximate composition. Rhodobacter sphaeroides strain UMSFW1 grow well by using settled Palm Oil Mill effluent (POME) as substrate and capable to remove TN in the settled POME and assimilate into bacterial biomass [6]. Rhodobacter sphaeroides Strain UMSFW1, a purple non-sulfur bacterium isolated from freshwater pond located inside University Malaysia Sabah (UMS) campus might be one of the potential candidates to utilize the finfish hatchery waste. In addition, no studies so far have been conducted with the utilization of finfish hatchery waste as substrate for the pro- 
duction of Rhodobacter sphaeroides Strain UMS2 biomass. This study was to determine nutrients that are available in the finfish hatchery waste so that can be used as substrate in culturing of Rhodobacter sphaeroides Strain UMS2 for the production of bacterium biomass in controlled environment.

\section{Materials and Methods}

\subsection{Collection of Fish Hatchery Waste}

Fish hatchery waste was collected from the University Malaysia Sabah (UMS) Finfish Hatchery every day from the main discharged point. The waste generated overnight in various tanks was cleaned up every day morning before the start of feeding. The waste water from UMS hatchery was collected for seven days. Immediately after collected, the waste was placed in oven for complete dry at a temperature of $60^{\circ} \mathrm{C}$. The samples were pulled (seven days sample) and mixed well after grinding into powder. It was stored in air tight plastic begs until further use.

\subsection{Analytical Parameters}

The analytical parameters like total solids $(\mathrm{mg} / \mathrm{L})$, ammonium nitrogen $(\mathrm{mg} / \mathrm{L}$, nitrite $(\mathrm{mg} / \mathrm{L}$, nitrate $(\mathrm{mg} / \mathrm{L}$ and phosphate $(\mathrm{mg} / \mathrm{L})$ were determined from the freshly collected liquid samples [7]. Total nitrogen (\%), total phosphorus (\%) and organic matter (\%) were determined from the dry samples with standard methods [7]. Estimation of crude protein was done using $\mathrm{Kjeltec}^{\mathrm{TM}} 2300 \mathrm{Au}$ to-analyzer Unit, crude fiber after hydrolysis with strong acid and alkali using Fibertec $^{\mathrm{TM}} 1020$ and crude fat extracted in petroleum ether using Soxtec ${ }^{\mathrm{TM}}$ System 2043 Extraction Unit of Foss Tecator, Sweden, and crude ash (\%) was determined using muffle furnace. This estimation was conducted according to the standard methods [7].

\section{Results}

The chemical composition of finfish hatchery effluent and solid waste are shown in Table 1 and Table 2 respectively. The ranges of concentration of chemical oxygen demand, ammonia, nitrate and phosphate were observed to be higher in

Table 1. Composition (mg/L) of UMS finfish hatchery effluent.

\begin{tabular}{ccc}
\hline Parameters $(\mathrm{mg} / \mathrm{L})$ & Mean Value & Range \\
\hline Chemical Oxygen Demand & 201 & $70-330$ \\
Total Solids & 79 & $75-82$ \\
Ammonia & 4.38 & $0.25-8.5$ \\
Nitrite & 0.98 & $0.05-1.9$ \\
Nitrate & 3.37 & $0.04-6.7$ \\
Phosphate-Phosphorus & 8.55 & $0.41-16.7$ \\
\hline
\end{tabular}


Table 2. Composition (\%) of UMS Finfish Hatchery Solid Wastes generated in fish tank.

\begin{tabular}{ccc}
\hline Parameters (\%) & Mean Value & Range \\
\hline Total Nitrogen & 3.75 & $1.6-5.8$ \\
Total Phosphorus & 1.80 & $0.98-2.72$ \\
Total Organic Matter & 7.75 & $5-10.5$ \\
Crude Proteins & 25 & $22-28$ \\
Crude Lipids & 5.85 & $4.5-7.2$ \\
Crude Fiber & 0.99 & $0.9-1.1$ \\
Ash & 34.58 & $25-44$ \\
Moisture & 5.75 & $5.1-6.4$ \\
\hline
\end{tabular}

the effluent observed (Table 1). Values in the mean concentration of dissolved inorganic nutrients, such as ammonia of $4.38 \mathrm{mg} / \mathrm{L}$, nitrate $(3.37 \mathrm{mg} / \mathrm{L})$ and phosphate of $8.55 \mathrm{mg} / \mathrm{L}$ were observed in the effluent that collected from various types of culture system.

The chemical composition of solid waste collected from the various culture systems of UMS hatchery shows less variation (Range value) compare to dissolve inorganic nutrients. However, the ranges of values in total nitrogen and total phosphorus were determined wider than the proximate composition of the solid waste (Table 2).

\section{Discussion}

\section{Composition of UMS Finfish Hatchery Effluent}

Two types of waste generated from UMS finfish hatchery, soluble and solid waste and they are both organic and inorganic. The wastewater from a UMS finfish hatchery is not different from that of a production farm in terms of quality and quantity of waste. The waste UMS finfish hatchery not only generated from larval rearing and fry production units, but also from other culture units. Those culture units include: brood fish rearing tank, experimental unit of fry, fingerling and grow out, green water production unit and live feed production unit. Thus, waste generated from all those units greatly influences the chemical composition compared to other waste generated from a single type of unit. The results from this study indicate that the mean values in dissolved inorganic nutrients (DIN) much higher, which might create the potential pollution consequences in the system. The negative effects of nutrients enrichment involve oxygen depletion, bad smell and the species will refuse to take feed, ultimately higher mortality. The concentration of DIN in this study, such as ammonia of $4.38 \mathrm{mg} / \mathrm{L}$, nitrate (3.37 mg/L) and phosphate of $8.55 \mathrm{mg} / \mathrm{L}$ were observed higher by other researchers [8]. They observed concentration of nutrients in fishpond increased as feed residue and fish excreta accumulated were in the range of $0.12-14.7 \mathrm{mg} / \mathrm{L}$ of $\mathrm{NH}_{4}-\mathrm{N}, 0.02-1.5 \mathrm{NO}_{2}-\mathrm{Nmg} / \mathrm{L}, 0.01-5.3 \mathrm{mg} / \mathrm{L}$ of $\mathrm{NO}_{3}-\mathrm{N}$, and $3.1-17.7$ $\mathrm{PO}_{4}-\mathrm{P} \mathrm{mg} / \mathrm{L}$. On the other hand, release of those DIN direct to environment 
leads to eutrophication problems and damage naturally balanced ecosystem. The consequences of lose inbio-diversity and blooming of harmful algal species, encourage to produce more and more toxic compounds in aquatic ecosystem. The variation in the chemical composition of finfish effluent are influenced by certain factors, such as, types of rearing tank, culture techniques, types of species and sizes of species, feed types and feed management, dynamics of nutrient in circulation and utilization, species handling techniques and the other physical chemical environment of the culture areas [9]. The dissolved inorganic nutrients that generated form finfish hatchery waste does not cause any harm in the environment upon disposal, which considered less significance compare to waste generated from agro-based and chemical industries [10]. The concentration of nutrients in aquaculture system increased with excess use of feed that remains un-eaten and also from the accumulation of fish excreta until bacterial activity. Only $20 \%-30 \%$ of the $\mathrm{N}$ and $\mathrm{P}$ input as feed is assimilated into fish tissue [11]. With respect to the pollution generated by aquaculture, nitrogen and phosphorus are considered as waste components of fish farming, causing serious environmental problems. In addition, several fish excrete nitrogenous waste products by diffusion and ion exchange through the gills, urine and feces. Decomposition and reuse of these nitrogenous compounds are especially important in aquaculture using recirculation systems due to the toxicity of ammonia and nitrite and the chance of hypertrophication of the environment by nitrate. Total solids generated in any aquaculture system from the uneaten fraction of feed as well as the excreted product from the fish gradually dissolved in water and increase the inorganic component so nutrients. In addition, opportunistic microbes in the system start to breakdown solids and converted into bacterial biomass while reducing the DIN in water. The solid generated in UMS hatchery in the range of $75-82 \mathrm{mg} / \mathrm{L}$ comparatively higher than reported by other researchers. Generally, solid concentrations in the untreated effluent from flow-through farms are around $5-50 \mathrm{mg} / \mathrm{L}$. The totals solids of $1.6-14.1 \mathrm{mg} / \mathrm{L}, 0.0-20.1 \mathrm{ng} / \mathrm{L}$ and $6.9 \mathrm{mg} / \mathrm{l}$ were reported by other researchers [12] [13] [14] but stated that these concentrations can vary widely depending on the management of aquaculture systems. Only $7 \%-32 \%$ of the total nitrogen (TN) and $30 \%-84 \%$ of the total phosphorus (TP) are originated from total solids in fish effluent. On the other hand, certain portion transported with the adsorption process and stay as settable solids. Thus macronutrients compositions are important in further use of these wastes to convert value added ingredients in live feed production system.

Rhodobacter sphaeroides strain UMSFW1 freshwater purple non-sulfphur bacterium (PNSB) has the capability to grow well by using settled Palm Oil Mill effluent (POME) as substrate and efficiently remove TN in the settled POME and assimilate into bacterial biomass. The UMS fish hatchery effluents rich of nutrients and are comparable to nutrients observed in POME. The hatchery wastes are basically rich in nitrogenous based substrate while the POME efflu- 
ents are carbon based substrate. The advantages of using purple non-sulfur bacteria are its ability to grow well in a wide range of substrates. The growth of $A f i$ fella marina, another marine isolate of PNSB using 112 synthetic media contain only one percent of yeast extract had showed a better growth in the production of cellular polymeric substances [5]. Other researchers [15] obtained $3.63 \mathrm{~g} / \mathrm{l}$ of Rhodobacter sphaeroides strain Z08 biomass while incubated in nutrient enriched media. It suggested that this strain of bacteria were fast growing and perhaps can be biotechnologically manipulated for large-scale production of single cell protein using waste as substrate [16]. Thus, the UMS fish hatchery effluent possesses more than sufficient enough to support the growth PNSB that can be used as substrate in culturing Rhodobacter sphaeroides Strain UMS2 for the production of bacterium biomass in controlled environment. However, this requires further investigations to observe the growth pattern of Rhodobacter sphaeroides Strain UMS2 under the optimized condition.

\section{Conclusion}

UMS finfish Hatchery wastes are enriched with nutrients. This waste can be used in bioprocess with the addition of inoculum from Rhodobacter sphaeroides strain UMS2 to obtained value added product. However, further experiment needs to design to identify the products that are valuable and added to bacterial biomass.

\section{Acknowledgements}

This study was supported by the grant of FRGS0481-2018 from Ministry of Education, Malaysia and authors also appreciated the support from staff of Borneo Marine Research Institute, University Malaysia Sabah, Kota Kinabalu, Sabah, Malaysia.

\section{Conflicts of Interest}

The authors declare no conflicts of interest regarding the publication of this paper.

\section{References}

[1] Oberdorff, T. and Porcher, J.P. (1994) An Index of Biotic Integrity to Assess Biological Impacts of Salmonid Farm Effluent on Receiving Waters. Aquaculture, 119 221-235. https://doi.org/10.1016/0044-8486(94)90177-5

[2] Tlusty, M.F., Bengston, D.A., Halvorson, H.O., Oktay, S.D., Pearce, J.B. and Rheault, R.B. (2001) Marine Aquaculture and the Environment: A Meeting for Stakeholders in the Northeast. Cape Cod Press, Falmouth.

[3] Ritchie, R.J. and Mekjinda, N. (2015) Measurement of Photosynthesis Using PAM Technology in a Purple Sulfur Bacterium Thermochromatium tepidum (Chromatiaceae). Photochemistry and Photobiology, 91, 350-358. https://doi.org/10.1111/php.12413

[4] Azad, S.A., Vikineswary, S., Chong, V.C. and Ramachandran, K.B. (2003) Rhodovu- 
Ium sulfidophilum in the Treatment and Utilization of Sardine Processing Wastewater. Letters in Applied Microbiology, 38, 13-18. https://doi.org/10.1046/j.1472-765X.2003.01435.x

[5] Azad, S., Tan, K. and Ransangan, J. (2013) Effects of Light Intensities and Photoperiods on Growth and Proteolytic Activity in Purple Non-Sulfur Marine Bacterium, Afifella marina Strain ME (KC205142). Advances in Bioscience and Biotechnology, 4, 919-924. https://doi.org/10.4236/abb.2013.410120

[6] Azad, S.A., Chin, F.S. and Lal, M.T.M. (2019) Efficacy of Purple Non Sulphur Bacterium Rhodobacter sphaeroides Strain UMSFW1 in the Utilization of Palm Oil Mill Effluent. Journal of Geoscience and Environment Protection, 7, 1-12. https://doi.org/10.4236/gep.2019.710001

[7] AOAC (2005) Standard Methods for the Examination of Water and Wastewater. Prepared and Published Jointly by American Public Health Association, American Water Works Association and Water Environment Federation 21st Edition, Washington DC.

[8] Lin, Y.F., Jing, S.R., Lee, D.Y. and Wang, T.W. (2002) Nutrient Removal from Aquaculture Wastewater Using a Constructed Wetlands System. Aquaculture, 209, 169-184. https://doi.org/10.1016/S0044-8486(01)00801-8

[9] Mudrak, V.A. (1981) Guidelines for Economic Commercial Fish Hatchery Wastewater Treatment Systems. In: Allen, L.J. and Kinney, E.C., Eds., Proceedings of the Bio-Engineering Symposium for Fish Culture, American Fisheries Society, Bethesda, 174-182.

[10] Doupe, R.G., Alder, J. and Lymbery, A.J. (1999) Environmental and Product Quality in Fin Fish Aquaculture Development: An Example from Inland Western Australia. Aquaculture Research, 30, 595-602. https://doi.org/10.1046/j.1365-2109.1999.00371.x

[11] Losordo, T.M. and Westers, H. (1994) System Carrying Capacity and Flow Estimation. In: Timmons, M.B. and Losordo, T.M., Eds., Aquaculture Water Reuse Systems. Engineering Design and Management, Elsevier, Amsterdam, 9-60.

[12] Hennessy, M., Wilson, L. and Struthers, W. (1991) Management Strategies for Salmon Farm Effluents. Scottish Salmon Growers Association, Perth.

[13] Bergheim, A., Kristiansen, R. and Kelly, L.A. (1993) Treatment and Utilization of Sludge from Land Based Farms for Salmon. In: Wang, J.-W., Ed., Techniques for Modern Aquaculture, American Society of Agriculture Engineers, St. Joseph, 486-495.

[14] Cripps, S.J. (1995) Serial Particle Size Fractionation and Characterization of an Aquaculture Effluent. Aquaculture, 133, 323-339.

https://doi.org/10.1016/0044-8486(95)00021-S

[15] Wu, P., Zhang, G. and Li, J. (2015) $\mathrm{Mg}^{2}+$ Improves Biomass Production from Soybean Wastewater Using Purple Non-Sulfur Bacteria. Journal of Environmental Sciences, 28, 43-46. https://doi.org/10.1016/j.jes.2014.05.040

[16] Tan, K.S., Azad, S.A. and Ransangan, J. (2014) Isolation and Characterization of Purple Non-Sulfur Bacteria, Afifella marina, Producing Large Amount of Carotenoids from Mangrove Microhabitats. Journal of Microbiology and Biotechnology, 24, 1034-1043. https://doi.org/10.4014/jmb.1308.08072 